\title{
Bacterial community shift in the coastal Gulf of Mexico salt-marsh sediment microcosm in vitro following exposure to the Mississippi Canyon Block 252 oil (MC252)
}

\author{
Hyunmin Koo $\cdot$ Nazia Mojib $\cdot$ Jonathan P. Huang $\cdot$ \\ Rona J. Donahoe $\cdot$ Asim K. Bej
}

Received: 9 February 2014/ Accepted: 4 June 2014/Published online: 10 July 2014

(C) The Author(s) 2014. This article is published with open access at Springerlink.com

\begin{abstract}
In this study, we examined the responses by the indigenous bacterial communities in salt-marsh sediment microcosms in vitro following treatment with Mississippi Canyon Block 252 oil (MC252). Microcosms were constructed of sediment and seawater collected from Bayou La Batre located in coastal Alabama on the Gulf of Mexico. We used an amplicon pyrosequencing approach on microcosm sediment metagenome targeting the V3-V5 region of the 16S rRNA gene. Overall, we identified a shift in the bacterial community in three distinct groups. The first group was the early responders (orders Pseudomonadales and Oceanospirillales within class Gammaproteobacteria), which increased their relative abundance within 2 weeks and were maintained 3 weeks after oil treatment. The second group was identified as early, but transient responders (order Rhodobacterales within class Alphaproteobacteria; class Epsilonproteobacteria), which increased their population by 2 weeks, but returned to the basal level 3 weeks after oil
\end{abstract}

Electronic supplementary material The online version of this article (doi:10.1007/s13205-014-0233-x) contains supplementary material, which is available to authorized users.

H. Koo $\cdot$ N. Mojib · J. P. Huang · A. K. Bej $(\bowtie)$

Department of Biology, University of Alabama at Birmingham,

1300 University Blvd., CH464, Birmingham, AL 35294-1170,

USA

e-mail: abej@uab.edu

URL: http://www.uab.edu/cas/biology/bej

\section{R. J. Donahoe}

Department of Geological Sciences, University of Alabama,

Tuscaloosa, AL 35487-0338, USA

Present Address:

N. Mojib

Red Sea Research Center, King Abdullah University of Science and Technology (KAUST), Thuwal, Saudi Arabia treatment. The third group was the late responders (order Clostridiales within phylum Firmicutes; order Methylococcales within class Gammaproteobacteria; and phylum Tenericutes), which only increased 3 weeks after oil treatment. Furthermore, we identified oil-sensitive bacterial taxa (order Chromatiales within class Gammaproteobacteria; order Syntrophobacterales within class Deltaproteobacteria), which decreased in their population after 2 weeks of oil treatment. Detection of alkane $($ alkB), catechol $(C 2,3 D O)$ and biphenyl ( $b p h)$ biodegradation genes by PCR, particularly in oil-treated sediment metacommunity DNA, delineates proliferation of the hydrocarbon degrading bacterial community. Overall, the indigenous bacterial communities in our salt-marsh sediment in vitro microcosm study responded rapidly and shifted towards members of the taxonomic groups that are capable of surviving in an MC252 oil-contaminated environment.

Keywords Oil spill · QIIME - Bioinformatics ·

Metagenomics - Pyrosequencing - Biodegradative genes . PCR

\section{Introduction}

The Gulf of Mexico (GoM) harbors a rich biota with ecological and high commercial significance (Yanez-Arancibia and Day 2004). In this ecosystem, the microorganisms are the primary consumers and play a major role in the biogeochemical cycling of organic matter (Pomeroy 1974). The GoM ecosystem is often perturbed by natural calamities or human activities, which affect the microbial community structure (Kryachko et al. 2012) and the associated nutrient cycling at all trophic levels (Pomeroy 1974; Camilli et al. 2010; Atlas and Hazen 2011). On April 20, 
2010 the Macondo Blowout, the largest accidental oil spill in the GoM and the second largest in the world, released an estimated 4.9 million barrels of crude oil (Atlas and Hazen 2011). This significant ecological perturbation of the sea and coastal region has led to negative impacts in local fishing, aquaculture and tourism (National Health Environmental Effects Research Laboratory (US) Gulf Ecology Division 1999; Yanez-Arancibia and Day 2004; ArreguinSanchez et al. 2004; Ritchie and Keller 2008). Since the occurrence of the oil spill, most studies used molecular approaches including NextGen sequencing technology to assess the diversity and metabolism of complex microbial communities in oil-contaminated environments, particularly samples collected from offshore locations surrounding the Macondo Blowout (Evans et al. 2004; Bordenave et al. 2007; Cappello et al. 2007; Liang et al. 2007; dos Santos et al. 2011; Kostka et al. 2011; Baelum et al. 2012; Beazley et al. 2012; Kim et al. 2012; Kryachko et al. 2012; Mason et al. 2012; Kimes et al. 2013). Overall, these studies showed that the impacts of oil on GoM indigenous microbial communities were dependent upon the location and the type of samples used. For example, the microbial communities when treated with oil in pristine sediments, showed an overall decrease in diversity, but the occasional emergence of oil-tolerant and hydrocarbonoclastic bacteria (HCB hereafter) was noticed. However, the communities that were exposed to crude oil released from natural oilseeps in the GoM ocean floor responded faster than the previously unoiled sediments (Kvenvolden and Cooper 2003). Moreover, the changes in the microbial diversity were found to be dependent upon the complexity of the petroleum hydrocarbon compounds and the length of treatment (Cappello et al. 2007). Although the adverse effects of the Macondo Blowout on the GoM's large open water and sediment ecosystems is indisputable, only a few studies have focused on the effect of MC252 oil on the coastal salt marsh microcosm environment (Beazley et al. 2012; Liu and Liu 2013). The coastal salt marsh along the GoM presents a delicately balanced, highly interactive, dynamic ecosystem that plays a crucial role in nutrient cycling, and serves as an important breeding ground and source of nutrients for coastal flora and fauna, including the Gulf seafood industry (Mitsch and Gosselink 2000; Engle 2011; Silliman et al. 2012; Beazley et al. 2012). Due to the relatively low tidal wave energy level, salt-marsh sediments and plants are capable of trapping and retaining spilt oil for years, often adversely affecting ecosystem structure and function (Mitsch and Gosselink 2000; Engle 2011; Silliman et al. 2012; Beazley et al. 2012). In this study, we evaluated the changes in the indigenous bacterial communities in salt marsh GoM coastal sediment microcosms in vitro following treatment with MC252 oil. We utilized the massively parallel bacterial tag-encoded FLX-amplicon pyrosequencing (bTEFAP) approach, targeting the $16 \mathrm{~S}$ small subunit (SSU) rRNA to obtain moderate to deep coverage that can also be efficiently processed by bioinformatics pipelines (Sogin et al. 2006; Dowd et al. 2008a, b). This approach has been shown to be effective in assessing the microbial community structure in complex ecosystems with high coverage (Acosta-Martinez et al. 2008; Sundarakrishnan et al. 2012). In addition, we have evaluated the presence of the bacterial biodegradative genes in oil-treated and untreated control sediment metacommunity DNA using the PCR method.

\section{Materials and methods}

Sample collection and sediment analysis

The sediment and seawater samples from Bayou La Batre, Alabama $\left(\mathrm{N} 30^{\circ} 22.714^{\prime} \mathrm{W} 088^{\circ} 18.230^{\prime}\right)$, were collected on March 17-31, 2011 in acid-washed plastic containers. The sediments were collected at a single location and placed in a 5 gallon acid-washed plastic bucket. The top $15-30 \mathrm{~cm}$ of sediments were sampled $15-30 \mathrm{~cm}$ beyond the edge of the salt marsh emergent aquatic macrophytes. The sediment sample was thoroughly homogenized by stirring and used for the microcosm setup. Seawater $\mathrm{pH}$ was measured using a combination $\mathrm{pH}$ electrode attached to a VWR Symphony SP90M5 meter, which was calibrated with standard buffer solutions to $+0.05 \mathrm{pH}$ unit. Seawater alkalinity was determined by titration using SM 2320B (American Water Works Association (AWWA) 2012). The measurements of total dissolved solids (TDS) were made using a METTLER AT261 DeltaRange balance and the gravimetric technique described in Method SM 2540C (AWWA 2012). An aliquot $(100 \mathrm{~g})$ of the sediment was crushed using a ceramic-lined SPEX 8510 Shatterbox, and then passed through a 400-mesh sieve. Sediment mineralogy was determined on bulk and oriented clay mounts by X-ray diffraction (XRD) analysis using a Bruker D8 advance diffractometer (Drever 1973). Also total petroleum hydrocarbons and total organic carbon (TOC) were determined by GC-MS using standard methods (Camilli et al. 2010; Pavlova and Papazova 2003; Roling et al. 2004) (Dr. Yuehan Lu, University of Alabama, Tuscaloosa, AL; personal communication) to confirm the initial level of oil, if any, that was present in the sediment samples. For each microcosm setup $326.94 \mathrm{~g}$ wet sediment (equivalent to $200 \mathrm{~g}$ dry weight each in glass jars) and $173.06 \mathrm{~g}$ seawater were placed in a $500 \mathrm{~mL}$ glass jar with a Teflonlined lid. Sterile sediments (autoclaved at $121{ }^{\circ} \mathrm{C}$ for $20 \mathrm{~min}$ at $15 \mathrm{lb} / \mathrm{sq}$ inch pressure) with oil and without oil were used as negative controls. The glass jars were combusted at $450{ }^{\circ} \mathrm{C}$ for $5 \mathrm{~h}$ prior to their use for the microcosm setup. Mississippi Canyon Block 252 oil (MC252) 
(50,000 ppm, $5 \%$ by weight) was added to each microcosm, gently mixed by shaking and incubated at room temperature $\left(20^{\circ} \pm 1^{\circ} \mathrm{C}\right)$ on a shaker table set at $100 \mathrm{rpm}$ to simulate wave action. Non-sterile sediment samples without MC252 oil (T0), used as controls to determine a baseline bacterial community, were also incubated simultaneously. Duplicate sediment samples were analyzed for metagenomics at different time points, time zero (T0, nonsterile untreated sediments), 2 weeks (T2, 2 weeks after the MC252 oil treatment), and 3 weeks (T3, 3 weeks after the MC252 oil treatment). Sediment samples (1 g each in triplicate) from the oil-treated and untreated microcosms (T0, T2 and T3), and oil-treated and -untreated sterile sediments were collected using aseptic techniques and the metacommunity DNA was extracted. High-quality metagenomic DNA was purified in triplicate from each microcosm sample using MoBio PowerSoil ${ }^{\circledR}$ DNA purification kit (MoBio Laboratories Inc., CA; http://www.mobio.com). The concentration (at $260 \mathrm{~nm}$ wavelength) and quality (a ratio of $260 / 280 \mathrm{~nm}$ wavelengths $=1.8 \pm 1$ ) of each extracted DNA sample were determined by a Lambda 2 spectrophotometer (Perkin Elmer, Norwalk, Conn.), followed by agarose gel electrophoresis in Tris-acetate-EDTA buffer (TAE, pH 7.8) (Ausubel et al. 1987). After confirming the purity and concentration, triplicate DNA samples from each oil-treated sediment were pooled and $100 \mathrm{ng}$ of DNA was used by the Research and Testing Laboratories (RTL) (Lubbock, Texas) (http://www.researchandtesting.com) for bacterial tag-encoded FLX-amplicon pyrosequencing (bTEFAP) (Dowd et al. 2008a). For the untreated controls, the same approach for purification and sequencing of DNA was used. The bTEFAP was performed as described previously (Dowd et al. 2008a; Sogin et al. 2006) using primers 341F (5'-CCT ACG GGA GGC AGC AG-3' (Muyzer et al. 1993) and 907R (5'-CCG TCA ATT CMT TTG AGT TT-3' (Lane et al. 1985) targeting the variable regions 3 and 5 (V3-V5) of the bacterial 16S rRNA gene (Li et al. 2009). Briefly, the initial generation of the sequencing library was performed by one-step PCR with HotStarTaq Plus Master Mix Kit (Qiagen, Valencia, CA) and 341F and 907R primers. The bTEFAP were conducted on a Roche 454 FLX instrument using the Titanium reagents and the procedure at RTL (Lubbock, TX).

Sequence processing and bioinformatic workflow

The Quantitative Insights Into Microbial Ecology software package (QIIME, ver.1.8.0) (Caporaso et al. 2010b) was used to analyze the raw barcoded pyrosequence reads from the bacterial $16 \mathrm{~S}$ rRNA gene. The low-quality sequence reads that did not match the barcode sequences, primer sequences, nucleotide homopolymers longer than $8 \mathrm{bp}$, ambiguous nucleotides $(\mathrm{N})$, had low-quality scores (quality score $<25$ ), or short length of reads ( $<200 \mathrm{bp}$ ) were removed from the library using split_libraries.py command. The sequences were clustered into operational taxonomic units (OTUs hereafter) at $97 \%$ sequence similarity using UCLUST (Edgar 2010). Representative sequences were selected from each OTU, aligned with PyNAST (version 1.1) (Caporaso et al. 2010a) (http://pynast.sourceforge.net/) and taxonomy was assigned to each representative sequence using RDP classifier (version 2.2) (Wang et al. 2007) (http://rdp.cme. msu.edu/) at $50 \%$ confidence. Previous studies have shown that bacterial taxonomy can be accurately predicted at this confidence level (Liu et al. 2008). The aligned representative sequences were then filtered and a phylogenetic tree was generated using FastTree (Price et al. 2009) (http://www. microbesonline.org/fasttree/). An OTU table was constructed through the aforementioned QIIME (ver. 1.8.0) workflow, which was subsequently used to generate the relative proportions of bacterial taxa in these communities.

\section{Microbial diversity statistics}

Further analyses of the bacterial diversity obtained through bTEFAP included estimating alpha and beta-diversity through the QIIME (ver. 1.8.0) software, based on the OTU table. Estimates of alpha-diversity include observed OTUs, Shannon diversity index (Shannon et al. 1964), and Simpson diversity index (Simpson 1949). The Shannon diversity index (Shannon et al. 1964) was defined as $H^{\prime}=\sum_{i=1}^{s}\left(p_{i} \ln p_{i}\right)$, where $s$ is the number of OTUs in the sample and $p_{i}$ is the proportion of the organisms in the sample represented by the $i$ th OTU. The Simpson diversity index (Simpson 1949) was defined as $1-\mathrm{D}$, where $D=1 / \sum p_{i}^{2}$ and $p_{i}$ is the proportion of the sample that OTU $i$ constitutes.

In order to calculate beta-diversity (differences between samples), a comparison of the bacterial communities in oiltreated and untreated samples was performed using UniFrac metrics (Lozupone et al. 2006) (http://bmf.colorado.edu/ unifrac/). Based on the weighted UniFrac phylogenetic distances, a principal coordinate analysis (PCoA) plot and Jackknife statistics were generated by the QIIME pipeline. Furthermore, the OTU table generated by QIIME (ver. 1.8.0) was modified and exported into Cytoscape 2.8.2 (Shannon et al. 2003) (http://www.cytoscape.org/), using the edge-weighted force-directed layout to visualize the data network (Pope et al. 2012). Cytoscape is a software that allows OTU-OTU interactions to be mapped to an OTU network to represent the bacterial similarities and differences between samples.

PCR amplification of biodegradative genes

The presence of bacterial genes involved in alkane, naphthalene, and catechol biodegradation in oil-treated or 
Table 1 List of oligonucleotide primers, target genes, and other relevant information used in this study for PCR amplification of the presence of the biodegradative genes in the sediment microcosm metacommunity DNA

\begin{tabular}{|c|c|c|c|c|c|c|}
\hline $\begin{array}{l}\text { Primer } \\
\text { name }\end{array}$ & Gene & Primer sequence $\left(5^{\prime}-3^{\prime}\right)$ & $\begin{array}{l}\text { Primer } \\
\text { length } \\
(\mathrm{nt})\end{array}$ & $\begin{array}{l}T_{\mathrm{m}} \\
\left({ }^{\circ} \mathrm{C}\right)^{\mathrm{a}}\end{array}$ & Origin & References \\
\hline$L$-alkB & \multirow{14}{*}{$\begin{array}{l}\text { Alkane } \\
\text { hydroxylase }\end{array}$} & gtatcgtgaacccaactaccgctcaat & 27 & 80 & \multirow[t]{2}{*}{ Pseudomonas oleovorans ATCC 29347} & \multirow{2}{*}{$\begin{array}{l}\text { Kok et al. } \\
\text { (1989) }\end{array}$} \\
\hline$R$-alkB & & ggtggaacaccactagatagagacg & 25 & 76 & & \\
\hline $\mathrm{Rh} \mathrm{L}-a l k B 1$ & & atctgggcgcgttgggatttgagcg & 25 & 80 & \multirow[t]{2}{*}{ Rhodococcus sp. strain Q15 } & \multirow{2}{*}{$\begin{array}{l}\text { Whyte et al. } \\
\text { (1998) }\end{array}$} \\
\hline Rh R-alkB1 & & cgcatggtgatcgctgtgccgctgc & 25 & 84 & & \\
\hline $\mathrm{Rh}$ L-alkB2 & & actctggcgcagtcgttttacggcc & 25 & 80 & \multirow[t]{2}{*}{ Rhodococcus sp. strain Q15 } & \multirow{2}{*}{$\begin{array}{l}\text { Whyte et al. } \\
\text { (1998) }\end{array}$} \\
\hline $\mathrm{Rh} \mathrm{R}-a l k B 2$ & & cccactgggcaggttgggcgcaccg & 25 & 88 & & \\
\hline $\begin{array}{l}\text { Rh } \\
\text { L-alkB194 }\end{array}$ & & cacagytggaacagygatcrc & 21 & 56 & \multirow[t]{2}{*}{$\begin{array}{l}\text { Rhodococcus sp. strain Q15 degenerate } \\
\text { primer to region common to alkb1 and alkb2 }\end{array}$} & \multirow{2}{*}{$\begin{array}{c}\text { Panicker } \\
\text { et al. } \\
(2010)\end{array}$} \\
\hline $\begin{array}{l}\mathrm{Rh} \\
\mathrm{R}-\text { alkB194 }\end{array}$ & & tccatcacyttkcgccacag & 20 & 56 & & \\
\hline L-alkB870G & & tggccggctactccgatgatcggaatctgg & 30 & 96 & \multirow[t]{2}{*}{ P. oleovorans ATCC 29347} & \multirow{2}{*}{$\begin{array}{l}\text { Van Beilen } \\
\text { et al. } \\
(2002)\end{array}$} \\
\hline $\begin{array}{l}\mathrm{R}- \\
\text { alkB870G }\end{array}$ & & cgcgtggtgatccgagtgccgctgaaggtg & 30 & 100 & & \\
\hline L-TS2S & & aayagagctcaygarytrggtcayaag & 27 & 60 & \multirow{2}{*}{$\begin{array}{l}\text { P. oleovorans GPo1 and Acinetobacter sp. } \\
\text { ADP1 }\end{array}$} & \multirow{2}{*}{$\begin{array}{l}\text { Phillips et al } \\
\text { (2000) }\end{array}$} \\
\hline R-deg1RE & & gtragictrgtrgtrcgcttaaggtg & 26 & 64 & & \\
\hline (Ac) alkM-F & & cetgtctcatttggcgctcgttcctacagg & 30 & 94 & \multirow[t]{2}{*}{ Acinetobacter $\mathrm{sp}$. ADP-1 } & \multirow{2}{*}{$\begin{array}{l}\text { Ratajczak } \\
\text { et al. } \\
\text { (1998) }\end{array}$} \\
\hline $\begin{array}{l}\text { (Ac) alkM- } \\
\mathrm{R}\end{array}$ & & ccaaagtggcggaatcatagcaggc & 25 & 78 & & \\
\hline L-ndoB & \multirow{2}{*}{$\begin{array}{l}\text { Naphthalene } \\
\text { dioxygenase }\end{array}$} & cactcatgatagcetgattcetgaccceggeg & 32 & 102 & \multirow[t]{2}{*}{ Pseudomonas putida ATCC 17484} & \multirow{2}{*}{$\begin{array}{c}\text { Kurkela } \\
\text { et al. } \\
\text { (1988) }\end{array}$} \\
\hline $\mathrm{R}-n d o B$ & & ccgtcccacaacacacccatgccgetgccg & 30 & 102 & & \\
\hline L-cat 238 & \multirow{6}{*}{$\begin{array}{l}\text { Catechol 2,3 } \\
\text { dioxygenase }\end{array}$} & cgacctgatctccatgaccga & 21 & 66 & \multirow{2}{*}{$\begin{array}{l}\text { Degenerate primer from conserved region of } \\
\text { C23DO gene in Pseudomonas sp. }\end{array}$} & \multirow{2}{*}{$\begin{array}{l}\text { Mesarch } \\
\text { et al. } \\
(2000)\end{array}$} \\
\hline R-cat 238 & & tcaggtcagcacggtca & 17 & 54 & & \\
\hline$x y l E b-F$ & & gtgcagctgcgtgtactggacatgagcaag & 30 & 94 & \multirow[t]{2}{*}{ Pseudomonas putida ATCC 33015} & \multirow{2}{*}{$\begin{array}{l}\text { Nakai et al. } \\
\text { (1983) }\end{array}$} \\
\hline$x y l E b-\mathrm{R}$ & & gcccagctggtcggtggtccaggtcaccgg & 30 & 104 & & \\
\hline cat $2,31 \mathrm{a}-\mathrm{F}$ & & aggtgctcggtttctacctggecg & 24 & 78 & \multirow[t]{2}{*}{ Pseudomonas putida ATCC 33015} & \multirow{2}{*}{$\begin{array}{l}\text { Laramee } \\
\text { et al. } \\
(2000)\end{array}$} \\
\hline cat2,3 6a-R & & acggtcatgaatcgttcgttgag & 23 & 68 & & \\
\hline $\operatorname{tod} C 1-\mathrm{F}$ & \multirow{2}{*}{$\begin{array}{l}\text { Toluene } \\
\text { dioxygenase }\end{array}$} & cgggtgggcttacgacaccgccggcaatct & 30 & 100 & \multirow[t]{2}{*}{ Pseudomonas putida $\mathrm{mt} 2$} & \multirow{2}{*}{$\begin{array}{c}\text { Panicker } \\
\text { et al. } \\
(2010)\end{array}$} \\
\hline todC1-R & & tcgagccgegetccacgetacccagacgtt & 30 & 100 & & \\
\hline bphA1-F & \multirow{2}{*}{$\begin{array}{l}\text { Biphenyl } \\
\text { dioxygenase }\end{array}$} & tcacctgcagctatcacggctgg & 23 & 74 & \multirow[t]{2}{*}{ Sphingomonas $35 / 1$} & \multirow{2}{*}{$\begin{array}{c}\text { Panicker } \\
\text { et al. } \\
(2010)\end{array}$} \\
\hline bphA1-R & & ggatctccacccagttctcgecatcgtcctg & 31 & 100 & & \\
\hline
\end{tabular}

${ }^{\mathrm{a}} T_{\mathrm{m}}\left({ }^{\circ} \mathrm{C}\right)=2(\mathrm{~A}+\mathrm{T})+4(\mathrm{G}+\mathrm{C})$ (Ausubel et al. 1987)

untreated control salt-marsh sediment metacommunity DNA were determined by PCR method. Oligonucleotide primers targeting the alkane hydroxylase (alk), an ISP (subunit of naphthalene dioxygenase) (ndoB), catechol 2,3dioxygenase $(C 2,3 D O)$, and toluene/biphenyl dioxygenase (todC1/bphAl) used in this study for PCR amplification are listed in Table 1. Genomic DNA from Rhodococcus sp., Pseudomonas putida ATCC 17484, P. putida $\mathrm{mt} 2$, and Sphingomonas 35/1 were used as positive controls for alkB, $n d o B, C 2,3 D O$, todCl, and $b p h$ amplification, respectively (Panicker et al. 2010). Each PCR amplification was performed in a $25-\mu$ l reaction volume consisting of $1 \mu \mathrm{g}$ of purified genomic DNA; $200 \mu \mathrm{M}$ of each of the dNTPs; $1 \mu \mathrm{M}$ of each of the oligonucleotide primer and $2.0 \mathrm{U}$ AmpliTaq (Perkin Elmer, Norwalk, CT) DNA polymerase; and $1 \times$ PCR reaction buffer $[10 \times$ buffer consisted of $300 \mathrm{mM}$ Tris-Cl (pH 9.0), $75 \mathrm{mM} \quad\left(\mathrm{NH}_{4}\right)_{2} \mathrm{SO}_{4}$, and $2.0 \mathrm{mM} \mathrm{MgCl}_{2}$ ] (Panicker et al. 2010). All PCR amplifications were performed in a GeneAmp PCR system 2400 (Perkin Elmer, Norwalk, CT) thermocycler using the following temperature cycling parameters: initial denaturation at $94{ }^{\circ} \mathrm{C}$ for 2 min followed by a total of 30 cycles of amplification in which each cycle consisted of denaturation at $94{ }^{\circ} \mathrm{C}$ for $1 \mathrm{~min}$, primer annealing at $60{ }^{\circ} \mathrm{C}\left(54{ }^{\circ} \mathrm{C}\right.$ for 
$C 2,3 D O$ and $56^{\circ} \mathrm{C}$ for alkB194) for $1 \mathrm{~min}$, and primer extension at $72{ }^{\circ} \mathrm{C}$ for $2 \mathrm{~min}$ (Table 1). After amplification, final extension of the incompletely synthesized DNA was carried out at $72{ }^{\circ} \mathrm{C}$ for $7 \mathrm{~min}$ (Panicker et al. 2010). The PCR fragments were analyzed by agarose gel electrophoresis $(1.5 \% \mathrm{wt} / \mathrm{vol})$ using a CloneSizer ${ }^{\mathrm{TM}} 100 \mathrm{bp}$ DNA ladder (Catalog\#: 11600, NORGEN Biotek Corp, Ontario, Canada) as a size standard. The gel was stained with ethidium bromide and visualized under a Photoprep I UV transilluminator (Fotodyne, Inc., Hartland, WI).

\section{Results}

Sea water and sediment samples

The seawater $\mathrm{pH}$ was 7.66, alkalinity $=83.07 \mathrm{mg} \mathrm{\textrm {CaCO } _ { 3 } /}$ $\mathrm{L}$, and total dissolved solids $=2,916 \mathrm{mg} / \mathrm{L}$ (brackish). The sediment mineralogy was largely quartz, with trace amounts of kaolinite, saponite, microcline and hematite. Sediment total petroleum hydrocarbon (TPH) concentration was below detection level in the original untreated sediment; and the sediment total organic carbon (TOC) ranged from $0.88-1.45 \%$ (Dr. Yuehan Lu, University of Alabama, Tuscaloosa, AL).

Total pyrosequencing reads and OTUs

A total of 8,172 partial (V3-V5) 16S rRNA "raw" sequence reads were generated by bTEFAP from the three microcosm samples. After stringent quality-based trimming, 5,264 quality reads were used for further bioinformatics analysis. Within these reads, 1,542 reads were clustered into 498 distinct OTUs (at $97 \%$ sequence similarity) from the T0 sample, 2,003 reads (908 OTUs at $97 \%$ sequence similarity) from the T2 sample, and 1,719 reads (282 OTUs at $97 \%$ sequence similarity) from the T3 sample were achieved. No quality pyrosequence reads were observed from the sterile negative control sediment samples.

\section{Taxonomy-based bacterial diversity}

The overall indigenous bacterial taxonomy represented by the Bayou La Batre, Alabama, salt-marsh sediment microcosm in vitro (oil-treated and untreated) was distributed amongst 15 defined phyla, 37 genera, and a few undefined taxa (referred to as "other" in this manuscript) (Fig. 1; Supplementary Table 1). Overall, the relative abundance of the bacterial communities in the 2- and 3-week untreated control samples were not significantly different when compared with the T0 sample; therefore, only the T0 data are presented in this manuscript (Fig. 1). Similar observations were reported in untreated water samples ( $0 \mathrm{~h}, 5$ days, and 20 days) from the Gulf of Mexico and mangrove sediment samples ( $0 \mathrm{~h}$ and 23 days) from Rio de Janeiro, Brazil (dos Santos et al. 2011; Baelum et al. 2012). The largest number of bacterial sequences identified in untreated sediments belonged to the phylum Proteobacteria and which, as compared to the T0 sample (at $69.4 \%$ of total bacterial load), increased in the T3 sample (74.8\%) (Fig. 1). Besides phylum Proteobacteria, phylum Firmicutes exhibited an overall increase in the T3 sample from undetectable to $4.4 \%$. Similarly, phyla Tenericutes and Actinobacteria increased from undetectable to 4.4, and 1.8 to $2.7 \%$, respectively, as compared to the T0 sample (Fig. 1). A decreasing trend of 2-4 times in the T3 sample was noticed for bacteria representing phyla Spirochaetes, Chloroflexi, WS3, Bacteriodetes, Nitrospira, Gemmatimonadetes, Chlorobi, and Cladithrix, whereas phyla Acidobacteria and Fusobacteria remained virtually unchanged (Fig. 1).

Because members of the phylum Proteobacteria dominated the bacterial community, we further analyzed the taxa within this phylum at the class (Fig. 2a) and genus levels (Fig. 3a). In the T0 sample, class Gammaproteobacteria constituted $\sim 43.6 \%$ of the total population, followed by Deltaproteobacteria (17.9\%). In the T3 sample, the microbial composition in Gammaproteobacteria increased to an approximately $59.3 \%$; and Deltaproteobacteria decreased to $10.7 \%$ (Fig. 2a). Furthermore, the classes Alphaproteobacteria and Epsilonproteobacteria first increased their relative abundances in the $\mathrm{T} 2$ and then decreased in the T3 sample (Fig. 2a). No significant change was noticed in Betaproteobacteria over the 21 day incubation in all three samples (Fig. 2a).

Further analysis of the members of Gammaproteobacteria determined that order Chromatiales (29.4\%) dominated the bacterial load followed by Oceanospirillales (3.6\%) in the T0 sample (Fig. 2b). In the T3 sample, order Chromatiales decreased to $10.9 \%$, whereas order Oceanospirillales increased from 3.6 to $16.6 \%$, Pseudomonadales from undetectable to $11.7 \%$, Methylococcales from undetectable to $16.1 \%$ (Fig. 2b). At the genus level within Gammaproteobacteria, Neptunomonas, Pseudomonas, and unclassified Oceanospirillaceae were increased in the T2 sample and maintained their population in the T3 sample (Fig. 3a). Oleibacter, Amphritea, and unclassified Pseudomonadaceae were increased in the $\mathrm{T} 2$ sample, but returned to the basal level in the T3 sample (Fig. 3a). Marinobacter, Thiomicrospira, and Marinobacterium were increased only in the T3 sample (Fig. 3a). Other genera, such as unclassified Marinicellaceae, OM60, Chromatiales, and Piscirickettsiaceae decreased in abundance in both the T2 and T3 samples (Fig. 3a). Class Deltaproteobacteria was dominated by order Syntrophobacterales $(6.1 \%)$ followed by the orders Desulfobacterales $(6.0 \%)$ 


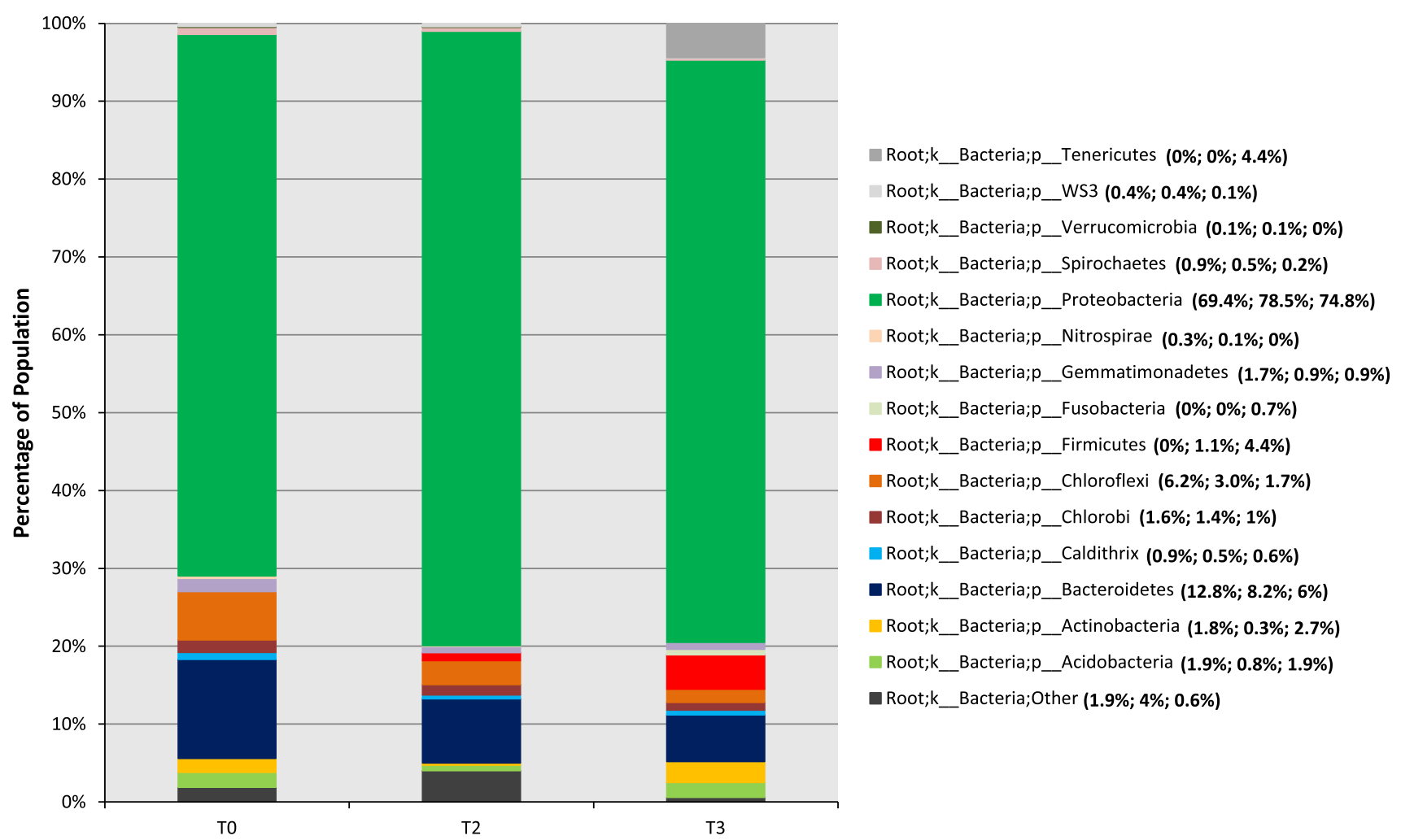

Fig. 1 Stacked column bar graph showing the relative abundance of the phyla distribution within the three microcosm samples collected from Bayou La Batre of coastal Alabama of the Gulf of Mexico. The

(a group exclusively belonging to the sulfur-reducing bacteria), Desulfuromonadales (3.4\%), and Myxococcales $(3.1 \%)$ in the T0 sample (Fig. 2b). There was a decreasing trend in the relative abundance within different orders of the class Deltaproteobacteria after oil treatment, except for a slight increase in both orders Syntrophobacterales, and Desulfobacterales at 21 days (T3) (Fig. 2b). At the genus level, Desulfuromonas and unclassified Desulfarculaceae increased in the $\mathrm{T} 2$ sample and maintained their population in the T3 samples. Genera Desulfobacter, Desulfococcus, and Desulfosarcina, increased in the T3 sample (Fig. 3a). Other genera, Desulfobacca, Desulfomonile, and members within families unclassified Desulfobacteraceae, Desulfobulbaceae, Desulfuromonadaceae, Myxococcales, and Haliangiaceae, decreased in relative abundance after the oil treatment (Fig. 3a).

Other genera, Thalassospira, Celeribacter, Phaeobact$e r$, and members of the family unclassified Rhodobacteraceae were found within class Alphaproteobacteria (Fig. 3a). The relative abundance of genus Celeribacter increased in both T2 and T3 while genus Thalassospira increased only in T3 (Fig. 3a). However, Phaeobacter and unclassified Rhodobacteraceae decreased in relative abundances after oil treatment (Fig. 3a). Within class Betaproteobacteria, we were able to identify unclassified percentage of each phylum is shown on the right side of the legend with the numbers corresponding to the $0 \mathrm{~h}$ non-sterile untreated control (T0), 2-week oil-treated (T2), and 3-week oil-treated (T3) samples

Betaproteobacteria, but their relative abundance remained unchanged after the oil treatment (Fig. 3a). Genera Arcobacter, Sulfurospirillum, and Sulfurimonas, within the class Epsilonproteobacteria were detected and increased their abundance in the T2 sample first, then returned to the basal level in the T3 sample (Fig. 3a).

Because members of the phylum Bacteroidetes are the second most abundant phylum in all three samples, we further analyzed the taxa within this phylum at the class level (Fig. 2c). Class Sphingobacteria dominated the bacterial load, followed by Flavobacteria and Bacteroidia in the T0 sample (Fig. 2c). However, in the T3 sample, the relative abundances of Sphingobacteria and Flavobacteria decreased (Fig. 2c). Although class Bacteriodia slightly decreased in the T2 sample, remained unchanged overall, comparing to the initial T0 number to that of the T3 sample (Fig. 2c). Most genera, Lewinella, Gaetbulibacter, Lutimonas, Muricola, unclassified Bacteroidales, Cytophagaceae, Flammeovirgaceae, and Flavobacteriaceae, within phylum Bacteroidetes decreased in population after the oil treatment, except Flavobacterium, Robiginitalea, and unclassified Sphingobacteriales (Fig. 3b). Flavobacterium increased their abundance only in the T2 sample, and Robiginitalea and unclassified Sphingobacteriales increased their population only in the T3 sample (Fig. 3b). 


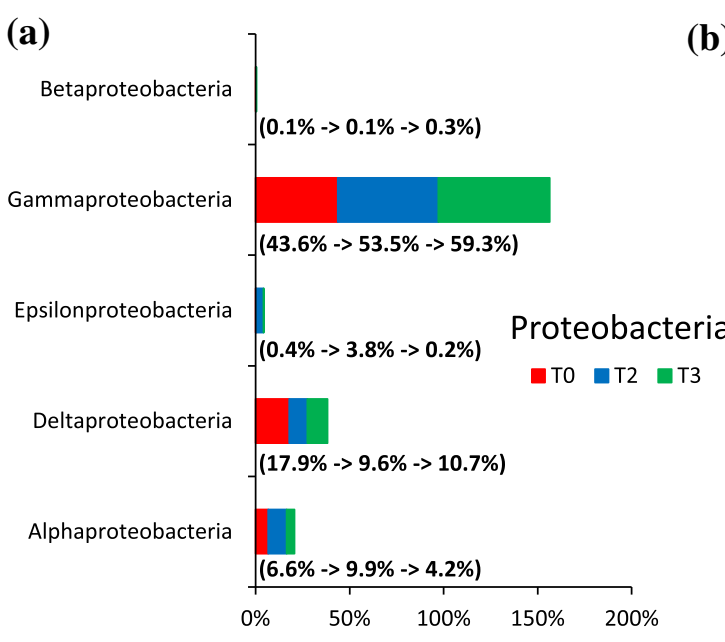

(c)

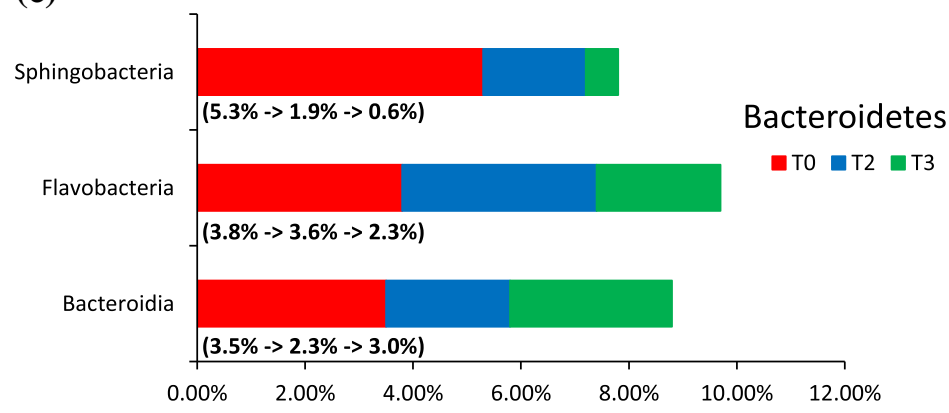

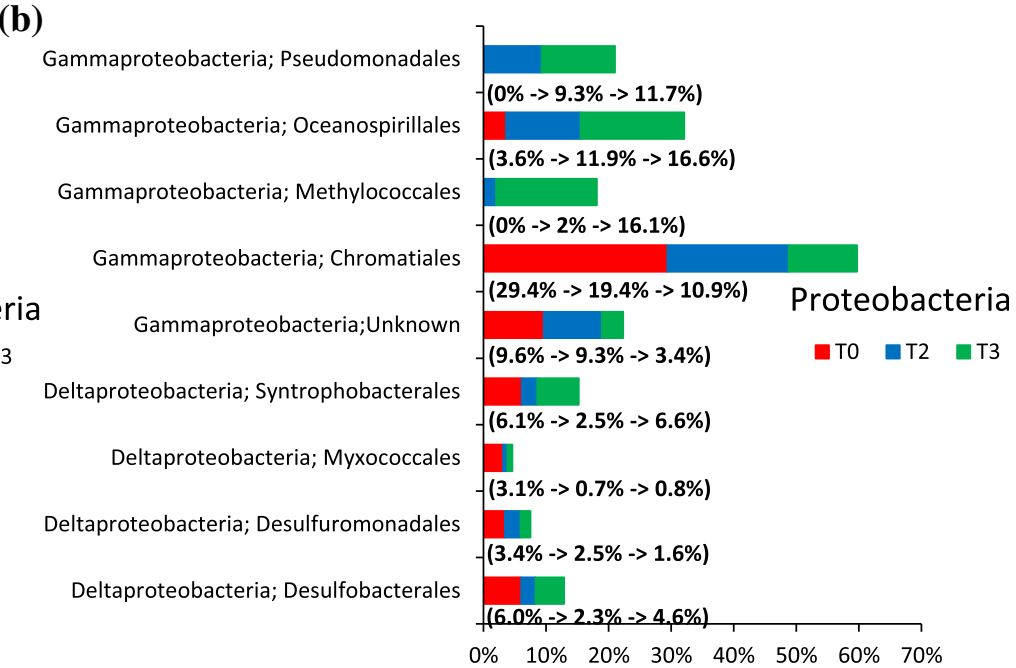

Fig. 2 Comparison of the three salt-marsh sediment samples showing the taxa at the order level in the non-sterile untreated (T0) sample and those treated with MC252 oil. a Distribution of class within phylum Proteobacteria; b distribution of order within phylum Proteobacteria;

We also detected genera Paenisporosarcina, Fusibacter, WH1-8, unclassified Acidaminobacteraceae and Clostridiales within phylum Firmicutes; all genera increased their abundance in sediments treated with oil (T2 and T3) (Fig. 3c). Paenisporosarcina, unclassified Acidaminobacteraceae, and Clostridiales increased in their relative abundance in the T2 sample and returned to the basal level in the T3 sample (Fig. 3c). However, Fusibacter and WH1-8 increased their relative abundance only in the T3 sample (Fig. 3c).

Statistics-based bacterial diversity

The Shannon diversity (Shannon et al. 1964) and Simpson diversity (Simpson 1949) indices exhibited a slight decrease in bacterial diversity in the oil-treated sediment sample (Table 2). Rarefaction curves indicated that total quality sequences from each of the microcosm experiments were approaching saturation when constructed at a $3 \%$ sequence variation (Fig. 4 ).

The relationships between the bacterial community structures among the three samples were further analyzed through the creation of an OTU network, and statistically c distribution of class within phylum Bacteroidetes. The percentage of each class and order level are shown on the right side of the legend with the numbers corresponding to the $0 \mathrm{~h}$ non-sterile untreated control (T0), 2-week oil-treated (T2), and 3-week oil-treated (T3) samples

compared using the weighted UniFrac. In the OTU network (Fig. 5a), each dot represents an OTU and each edge represents different sediment samples (T0 in red, $\mathrm{T} 2$ in blue, and T3 in green). The OTU network clearly shows that each of the microcosm samples has their own unique bacterial community, but many OTUs are shared between the T0 and T2 samples (Fig. 5a). Furthermore, the PCoA plot demonstrated that there were significant differences in the bacterial community structure between the three samples (Fig. 5b). These results indicated that the oil treatment resulted in shifting the microbial community structure over the course of the experiment.

\section{Biodegradative genes}

The PCR amplification targeting the biodegradative genes in purified metacommunity DNA from oil-treated sediments exhibited positive detection of alkane hydroxylase (alkB), catechol 2,3-dioxygenase $(C 2,3 D O)$, and biphenyl dioxygenase $(b p h)$ biodegradative genes (Table 3$)$. Positive amplification of the biphenyl dioxygenase $(b p h)$ gene in the T0 sample indicates that HCB exist in the GoM salt- 


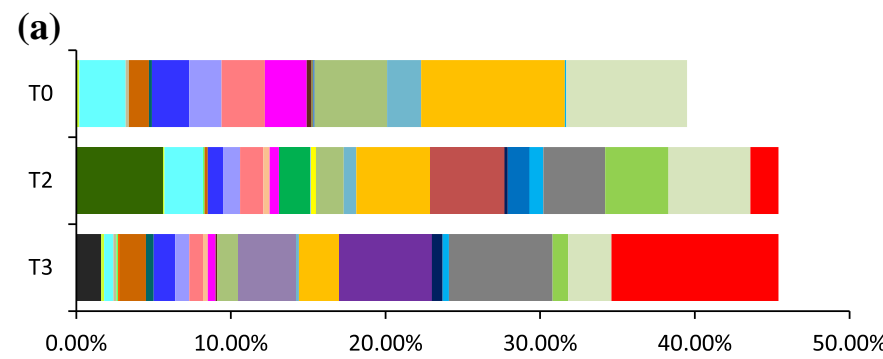

(b)

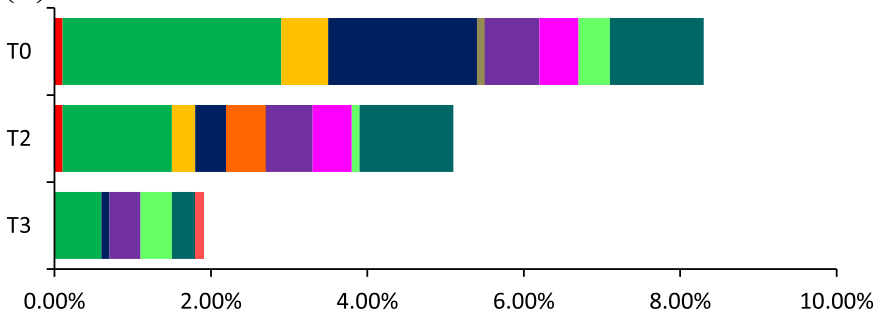

(c)

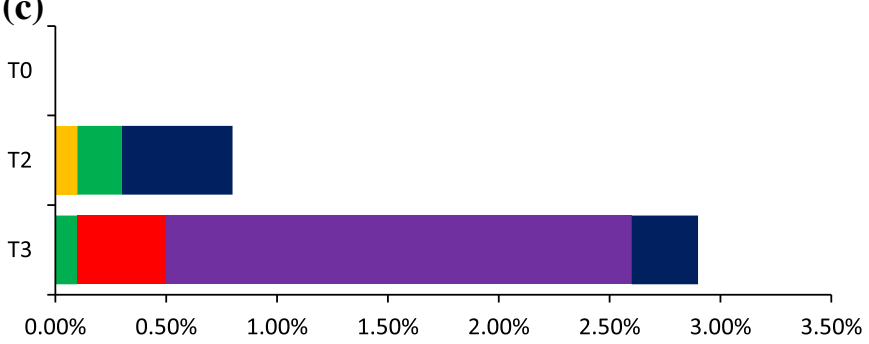

Fig. 3 Stacked column bar graph showing the relative abundances of genera in the $0 \mathrm{~h}$ non-sterile untreated control (T0), 2-week oiltreated (T2) and 3-week oil-treated (T3) microcosm samples. The

Table 2 Number of sequences and OTUs, Shannon diversity and Simpson diversity indices, calculated based upon bacterial 16S rRNA gene sequences in the datasets of the $0 \mathrm{~h}$ non-sterile untreated control (T0), 2-week oil-treated (T2), and 3-week oil-treated (T3) microcosm samples, determined using QIIME (ver. 1.8.0)

\begin{tabular}{lllll}
\hline Samples & $\begin{array}{l}\text { Number of } \\
\text { sequences }\end{array}$ & $\begin{array}{l}\text { Number of } \\
\text { OTUs }\end{array}$ & $\begin{array}{l}\text { Shannon } \\
\text { diversity index }\end{array}$ & $\begin{array}{l}\text { Simpson } \\
\text { diversity index }\end{array}$ \\
\hline T0 & 1,542 & 498 & 8.474 & 0.995 \\
T2 & 2,003 & 908 & 8.425 & 0.99 \\
T3 & 1,719 & 282 & 6.443 & 0.964 \\
\hline
\end{tabular}

marsh sediment, and were likely enriched following oil treatment due to a shift of the indigenous bacterial population.

\section{Discussion}

The application of bTEFAP and downstream bioinformatic analyses on the metacommunity DNA indicated that the
Thalassospira

Phaeobacter

Unclassified Betaproteobacteria

Desulfobacter

- Desulfosarcina

Unclassified Desulfobulbaceae

- Desulfuromonas

Unclassified Haliangiaceae

Desulfomonile

Sulfurospirillum

- Unclassified Marinicellaceae

Unclassified OM60

Amphritea

- Neptunomonas

Unclassified Oceanospirillaceae

Unclassified Pseudomonadaceae

Thiomicrospira

- Lewinella

Unclassified Cytophagaceae

Flavobacterium

- Lutimonas

Robiginitalea

Unclassified Sphingobacteriales
Celeribacter

Unclassified Rhodobacteraceae

- Unclassified Desulfarculaceae

Desulfococcus

Unclassified Desulfobacteraceae

Unclassified Desulfuromonadaceae

- Unclassified Myxococcales

Desulfobacca

Arcobacter

Sulfurimonas

- Marinobacter

- Unclassified Chromatiales

Marinobacterium

- Oleibacter

- Pseudomonas

Unclassified Piscirickettsiaceae

Unclassified Bacteroidales

- Unclassified Flammeovirgaceae

Gaetbulibacter

Muricola

- Unclassified Flavobacteriaceae
Paenisporosarcina

- Unclassified Acidaminobacteraceae

- Fusibacter

- WH1-8

- Unclassified Clostridiales

figure shows the genus level distribution within a phylum Proteobacteria; b phylum Bacteroidetes; and c phylum Firmicutes

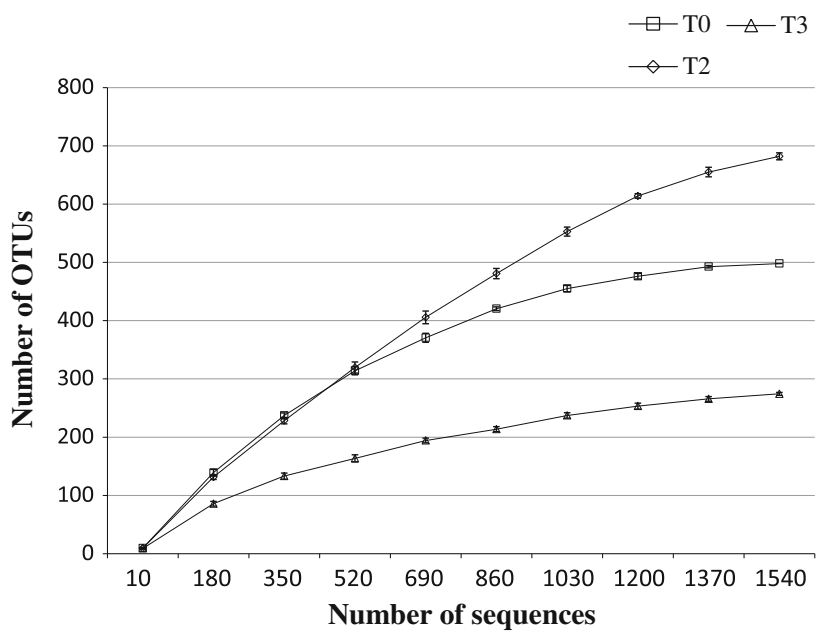

Fig. 4 Rarefaction curves based upon bacterial 16S rRNA genes generated after normalizing the data for the number of sequence$\mathrm{s}$ obtained from the $0 \mathrm{~h}$ non-sterile untreated control (T0), 2-week (T2) and 3-week (T3) oil-treated microcosm samples. The number of unique OTUs at $3 \%$ sequence variations and standard deviation was calculated by QIIME (ver. 1.8.0) 
(a)

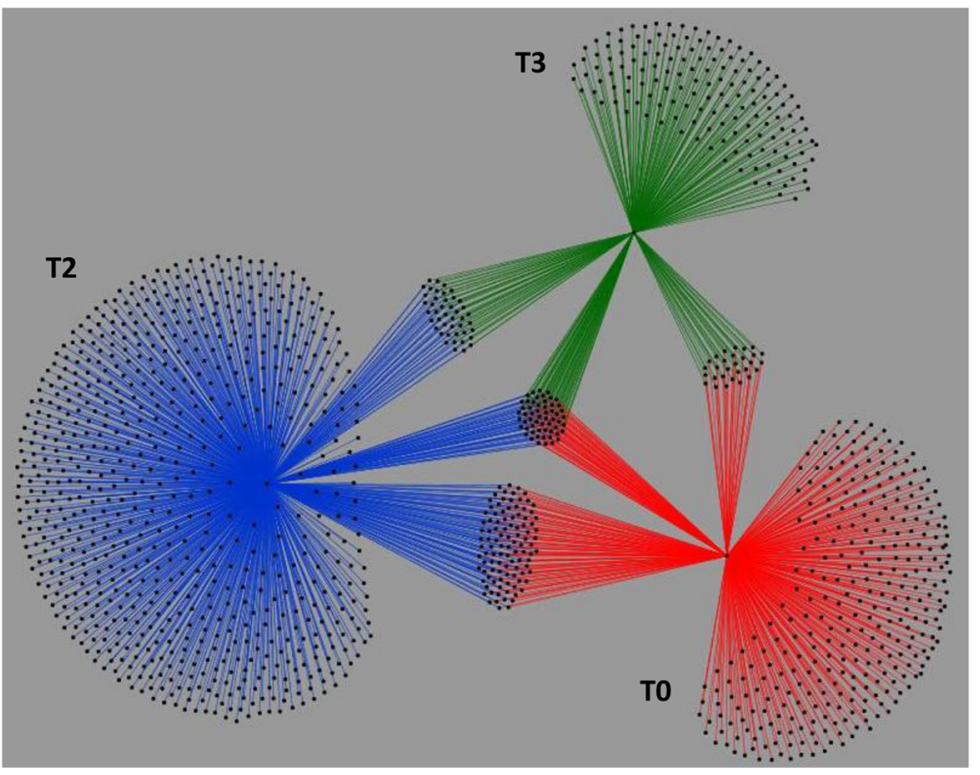

(b)

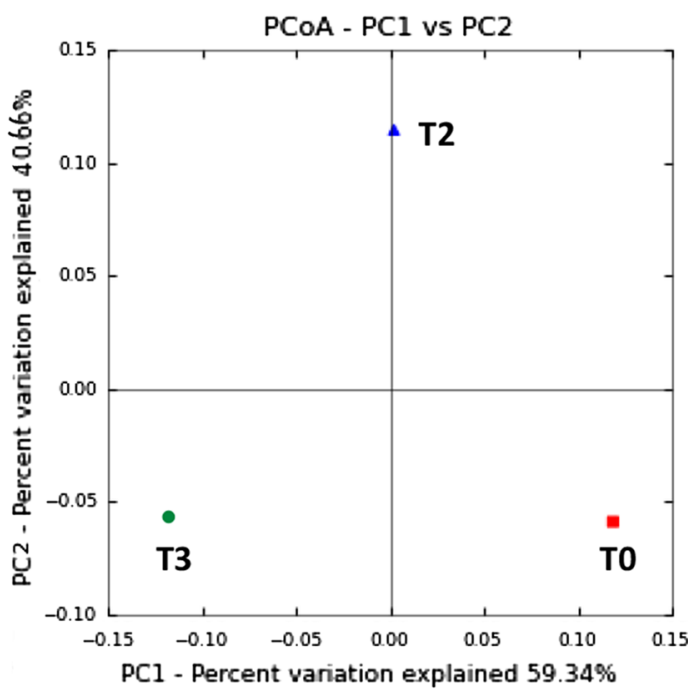

Fig. 5 Operational taxonomic unit (OTU) network and PCoA (principle coordinate analysis) plot. a OTU network analysis to evaluate the effect of oil treatment through the relationship between OTUs (each dot) in the three different microcosm samples. Edges of the $0 \mathrm{~h}$ non-sterile untreated control sample (T0) are represented in

salt-marsh sediments of Bayou La Batre in coastal Alabama contain a diverse bacterial community with phylum Proteobacteria, as the dominant taxa. Similar result was previously reported for mangrove and salt-marsh sediments by studies using molecular approaches, including the 454 pyrosequencing (Liang et al. 2007; dos Santos et al. 2011; Beazley et al. 2012; Liu and Liu 2013). Although the results from this study show that the oil treatment altered the overall bacterial communities, it is important to identify how these communities differed in the treated and the untreated control sample at various taxa levels. To achieve this, we first identified the OTUs, followed by monitoring significant changes in their relative abundances in the oil-treated samples (Figs. 1, 2, 3). Based upon these analyses, we were able to categorize three distinct groups of bacteria: (1) early responders, which increased their relative abundance by the second week of treatment (T2); (2) early, transient responders, which increased in relative abundance by the second week (T2), but returned to the basal level (i.e., that of the untreated sediment) by the third week of oil treatment (T3); and (3) late responders, which increased only after 3 weeks of oil treatment (T3).

The early responders, which belonged to the class Gammaproteobacteria and order Pseudomonadales, were only detected in the oil-treated samples. At the genus level, we detected Pseudomonas as an early responder (Fig. 3a). It has been reported that bacteria belonging to order red, the 2-week oil-treated sample (T2) in blue, and the 3-week oiltreated sample (T3) in green. b The PCoA plot based on weighted UniFrac shows the differences and similarities between the bacterial communities from each microcosm experiment

Pseudomonadales are capable of biodegradation of alkanes and naphthalene by using genetic systems present on the OCT-plasmid (Kok et al. 1989; van Beilen et al. 1994). Detection of this genus in our study was supported by the PCR-positive results of alkane and catechol degradation genes (Table 3), and an increase in their abundance in both the T2 and T3 samples (Fig. 2b). Another early responder, order Oceanospirillales (class Gammaproteobacteria), increased rapidly in the $\mathrm{T} 2$ sample, and then continued to increase, but at a slower rate, in the T3 sample (Fig. 2b). At the genus level, we found Neptunomonas and unclassified Oceanospirillaceae as early responders (Fig. 3a). Previous studies showed that Oceanospirillales proliferate rapidly in oil-enriched environments and are capable of mineralizing $n$-alkane and cycloalkane (Hazen et al. 2010; dos Santos et al. 2011; Redmond and Valentine 2012; Mason et al. 2012; Baelum et al. 2012; Chakraborty et al. 2012). Also, previous study has supported hydrocarbon degradation activity by genus Neptunomonas (Hedlund et al. 1999).

Among the transient responders, we identified order Rhodobacterales belonging to the class Alphaproteobacteria, which increased in the T2 sample and then decreased in the T3 sample (data not shown). At the genus level, Celeribacter was assigned as transient responders and they increased their abundance after the oil treatment (Fig. 3a). Previously, members of the order Rhodobacterales were detected in oilenriched environments and described to have the ability to 


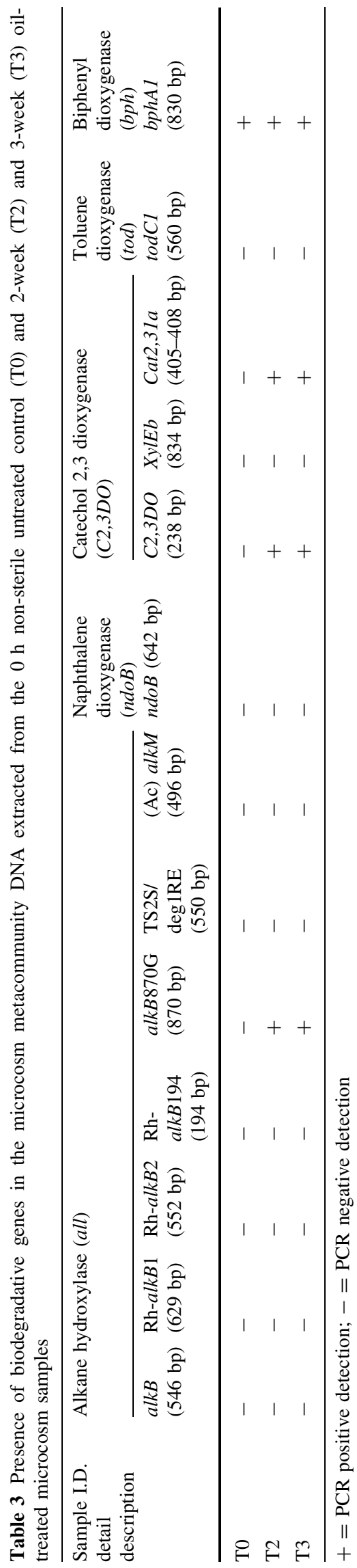

degrade hydrocarbon compounds (Brakstad and Lodeng 2005; Hernandez-Raquet et al. 2006; Chakraborty et al. 2012; Redmond and Valentine 2012; Baelum et al. 2012). The genera Amphritea, Oleibacter, and unclassified Pseudomonadaceae belonging to the class Gammaproteobacteria also increased their relative abundance as transient responders in the T2 sample. It has been reported in a previous study tha$t$ although members of the class Gammaproteobacteria although steadily increased up to 26 days following oil treatment, they were replaced by Alphaproteobacteria over time. This is perhaps due to the ability of the Alphaproteobacteria to utilize residual PAHs or the byproducts of alkanes (Roling et al. 2002). Similarly, we found that the abundance of Gammaproteobacteria steadily increased in the T2 and T3 samples (Sette et al. 2007). Interestingly, the abundance of Alphaproteobacteria (genus Celeribacter) and Epsilonproteobacteria (genera Arcobacter, Sulfurospirillum, and Sulfurimonas) increased in the T2 sample, but unlike other studies, decreased in the T3 sample (Figs. 2a, 3a). It has been reported that members of the class Epsilonproteobacteria are the key players in nitrogen and sulfur cycling in marine environments and are capable of withstanding hydrocarbons in contaminated environments (Wirsen et al. 2002; Grabowski et al. 2005; Campbell et al. 2006; Gupta 2006; Sette et al. 2007; Prabagaran et al. 2007; Herrmann et al. 2010; Hubert et al. 2012). The reason for the decrease in the relative abundance of Alphaproteobacteria, especially genera Phaeobacter and unclassified Rhodobacteraceae in the T3 sample remains unclear. Other genera such as Flavobacterium were assigned as transient responders and their hydrocarbon degrading activity has been reported in a previous study (Hemalatha and Veeramanikandan 2011).

The late responders belonged primarily to the order Clostridiales within phylum Firmicutes, which have been known to degrade hydrocarbons and to be an indicator bacteria in oil-contaminated environments (Howarth 1984; Bordenave et al. 2007; dos Santos et al. 2011; Mason et al. 2012). These were not detected in the untreated control sediment, but increased rapidly in the T3 sample (data not shown). Within phylum Firmicutes, genera Fusibacter and WH1-8 were late responders; Fusibacter, especially, has been reported to degrade crude oil (Hasegawa et al. 2014). The members of class Mollicutes within the phylum Tenericutes also appeared as late responders in our study and only detected in the T3 sample (data not shown). In addition, Methylococcales from class Gammaproteobacteria showed a significant increase in the T3 sample (Fig. 2b), which is similar to previous reports that this bacteria increased in their relative abundance in oil-treated environments and bloomed slowly, compared to other bacteria (Mason et al. 2012; Chakraborty et al. 2012; Redmond and Valentine 2012; Baelum et al. 2012). Within the phylum Proteobacteria, genera such as Thalassospira, 
Desulfobacter, Desulfococcus, Desulfosarcina, Marinobacter, Marinobacterium, and Thiomicrospira were late responders because they increased their relative abundance in the T3 sample. According to previous studies, genera Desulfobacter, Desulfococcus, and Desulfosarcina are known to be sulfate-reducing bacteria (Elshahed et al. 2003), and Marinobacter, Marinobacterium, and Thalassospira show hydrocarbon degrading activity of crude oil (Deppe et al. 2005; Yakimov et al. 2007; Kostka et al. 2011). Also, within the phylum Bacteroidetes, genera Robiginitalea, and unclassified Sphingobacteriales were late responders and known as hydrocarbon degrading bacteria (Kostka et al. 2011).

Further, as reported for the mangrove ecosystems in Brazil (Cappello et al. 2007), we identified members from order Chromatiales (within class Gammaproteobacteria) and order Syntrophobacterales (within class Deltaproteobacteria) to be sensitive to oil treatment, as shown by their decreased relative abundance in the T2 sample (Fig. 2b).

Order Chromatiales within class Gammaproteobacteria consisted of family Chromatiaceae and Ectothiorhodospiraceae-a group of sulfur-oxidizing bacteria that exhibited a steadily decreasing trend in oil-treated sediments. Similarly, class Deltaproteobacteria dominated by the order Syntrophobacterales, consisting of anaerobic sulfate-reducing bacteria, also decreased in the T2 sample but increased in the T3 sample. It has long been established that salt-marsh sediments have high levels of sulfur from the sea water and abundant sulfur oxidizing and sulfatereducing bacteria found in these ecosystems, and they contribute to the sulfur biogeochemical cycle (Howarth 1984; Teal 1986; Devereux et al. 1996; Glória Pereira et al. 2002; Klepac-Ceraj et al. 2004). Therefore, results of our bTEFAP analysis can likely be explained by the high sulfur content of the salt-marsh sediment and local microaerophilic conditions induced by the oil, which increased a selective group of sulfur-oxidizers, leading to increased sulfur oxidation. This was in concert with the simultaneous decrease in the sulfur reducing group of class Deltaproteobacteria in the T2 sample. But after 2 weeks, due to the intense activities of sulfur-oxidizing bacteria, we suspect that there was depletion of oxygen and severe acidification, leading to an increase in the sulfur-reducing bacteria belonging to the class Deltaproteobacteria. Sulfate-reducing bacteria (class Deltaproteobacteria) have often been found in marine sediments associated with hydrocarbons (Teal 1986; Phelps et al. 1998; Roling et al. 2004; Kimes et al. 2013). The microaerophilic or anoxic conditions of the treated sediment samples were also indicated by the presence of sequences affiliated with an anaerobic group of bacteria mentioned above, and were not present in the untreated sample.
For the bTEFAP metagenomic sequence library, the plateau in a rarefaction curve (Hughes and Hellmann 2005) suggests that the ecosystem has been sampled to saturation with respect to species diversity (Fig. 4). The weighted UniFrac test that accounts for changes in the relative abundances of lineages between communities (Lozupone et al. 2007) showed that bacterial taxa in the T0 sample have greater similarity to those in the T2 sample than to those in the T3 sample (Fig. 5b). This result suggests that the typically undetectable oil-tolerant HCB proliferated shortly after oil treatment and were therefore detected in the T2 sample. We analyzed the microbial response to MC252 oil following 2- and 3-week treatment, because it has been reported that the HCB population is established within 2 weeks as a response to rapid biodegradation events (Head et al. 2006; Yakimov et al. 2007). Overall, the richness of the microbial communities in the treated sediments increased in the T2 sample and then decreased in the T3 sample (Table 2). This implies that perhaps the indigenous HCB flourished, as their presence in the GoM ecosystem, due to the natural seepage of oil or oil-related anthropogenic activities. The decrease in bacterial richness and diversity in the T3 sample was probably due to the growth-limiting toxic effect of polyaromatic hydrocarbons on the oil-sensitive bacteria in the sediments. Furthermore, in this study, PCR amplification of a suite of signature petroleum hydrocarbon degrading genes from oil-treated and untreated sediment metacommunity DNA revealed the presence of alkane and catechol degradation genes only in oil-treated salt-marsh sediments. The presence of these genes in the proliferating hydrocarbon-degrading HCB, particularly in the T2 and T3 samples, supports the availability of biodegradable alkanes, biphenyl and other aromatic hydrocarbons as substrates in the MC252 oil (Mason et al. 2012). Moreover, bacterial taxa capable of actively utilizing the aforementioned hydrocarbon compounds have been described in the previous section.

The present investigation of the indigenous microbial communities of salt-marsh sediments from coastal Alabama and assessment of the impact of oil treatment conducted in vitro utilizing sediment-seawater microcosms, identified the presence of a highly diverse, adaptable, and sustainable microbial community capable of shifting its population dynamics to combat ecological perturbations. These results also revealed the capability and efficiency of targeted metagenomics (bTEFAP) technology (Sogin et al. 2006; Dowd et al. 2008a) in detecting rare groups by providing a fine-resolution map of microbial community structure at different taxonomic levels.

Acknowledgments This work was supported by the Gulf of Mexico Research Initiative (GoMRI) grant, which was distributed by Alabama Marine Environmental Science Consortium (MESC) (Project Number: T1-001-DISL); we thank Dr. John Valentine of DISL, Dr. Patricia Sobecky of University of Alabama, Tuscaloosa (UA), for 
selecting the proposal for support; and Erika Rentschler of UA for technical assistance. We also thank Yuehan Lu, University of Alabama, Tuscaloosa, AL, for providing the results of the GC-MS analysis of the sediment samples; John Delton Hanson of Research and Testing Laboratory, TX for assisting us with the bTEFAP of the samples; Katherine V. Hughes and Matthew Pace of UAB CAS IT for computer support.

Conflict of interest The authors declare no conflict of interest with this study.

Open Access This article is distributed under the terms of the Creative Commons Attribution License which permits any use, distribution, and reproduction in any medium, provided the original author(s) and the source are credited.

\section{References}

Acosta-Martinez V, Dowd S, Sun Y, Allen V (2008) Tag-encoded pyrosequencing analysis of bacterial diversity in a single soil type as affected by management and land use. Soil Biol Biochem 40(11):2762-2770

American Water Works Association (AWWA) (2012) Standard Methods for the Examination of Water and Wastewater, vol 22ed. Washington: American Public Health Association (APHA) 22 ed: 1360

Arreguin-Sanchez F, Zetina-Rejon M, Manickchand-Heileman S, Ramirez-Rodriguez M, Vidal L (2004) Simulated response to harvesting strategies in an exploited ecosystem in the southwestern Gulf of Mexico. Ecol Model 172(2-4):421-432

Atlas RM, Hazen TC (2011) Oil biodegradation and bioremediation: a tale of the two worst spills in U.S. history. Environ Sci Technol 45(16):6709-6715

Ausubel FM, Brent R, Kingston RE, Moore DD, Smith JG, Sideman JG, Struhl K (1987) Short protocols in molecular biology: a compendium of methods from current protocols in molecular biology. Wiley, New York

Baelum J, Borglin S, Chakraborty R, Fortney JL, Lamendella R, Mason OU, Auer M, Zemla M, Bill M, Conrad ME, Malfatti SA, Tringe SG, Holman HY, Hazen TC, Jansson JK (2012) Deep-sea bacteria enriched by oil and dispersant from the Deepwater Horizon spill. Environ Microbiol 14(9):2405-2416

Beazley MJ, Martinez RJ, Rajan S, Powell J, Piceno YM, Tom LM, Andersen GL, Hazen TC, Van Nostrand JD, Zhou J, Mortazavi B, Sobecky PA (2012) Microbial community analysis of a coastal salt marsh affected by the Deepwater Horizon oil spill. PLoS One 7(7):e41305

Bordenave S, Goni-Urriza MS, Caumette P, Duran R (2007) Effects of heavy fuel oil on the bacterial community structure of a pristine microbial mat. Appl Environ Microbiol 73(19): 6089-6097

Brakstad OG, Lodeng AG (2005) Microbial diversity during biodegradation of crude oil in seawater from the North Sea. Microb Ecol 49(1):94-103

Camilli R, Reddy CM, Yoerger DR, Van Mooy BA, Jakuba MV, Kinsey JC, McIntyre CP, Sylva SP, Maloney JV (2010) Tracking hydrocarbon plume transport and biodegradation at Deepwater Horizon. Science 330(6001):201-204

Campbell BJ, Engel AS, Porter ML, Takai K (2006) The versatile epsilon-proteobacteria: key players in sulphidic habitats. Nat Rev Microbiol 4(6):458-468

Caporaso JG, Bittinger K, Bushman FD, DeSantis TZ, Andersen GL, Knight R (2010a) PyNAST: a flexible tool for aligning sequences to a template alignment. Bioinformatics 26(2): 266-267

Caporaso JG, Kuczynski J, Stombaugh J, Bittinger K, Bushman FD, Costello EK, Fierer N, Pena AG, Goodrich JK, Gordon JI, Huttley GA, Kelley ST, Knights D, Koenig JE, Ley RE, Lozupone CA, McDonald D, Muegge BD, Pirrung M, Reeder J, Sevinsky JR, Turnbaugh PJ, Walters WA, Widmann J, Yatsunenko T, Zaneveld J, Knight R (2010b) QIIME allows analysis of high throughput community sequencing data. Mat Methods 7(5):335-336

Cappello S, Caruso G, Zampino D, Monticelli LS, Maimone G, Denaro R, Tripodo B, Troussellier M, Yakimov M, Giuliano L (2007) Microbial community dynamics during assays of harbour oil spill bioremediation: a microscale simulation study. J Appl Microbiol 102(1):184-194

Chakraborty R, Borglin SE, Dubinsky EA, Andersen GL, Hazen TC (2012) Microbial response to the MC-252 oil and corexit 9500 in the Gulf of Mexico. Front Microbiol 3:357

Deppe U, Richnow HH, Michaelis W, Antranikian G (2005) Degradation of crude oil by an arctic microbial consortium. Extremophiles 9(6):461-470

Devereux R, Hines M, Stahl D (1996) S cycling: characterization of natural communities of sulfate-reducing bacteria by 165 rRNA sequence comparisons. Microb Ecol 32(3):283-292

dos Santos HF, Cury JC, do Carmo FL, dos Santos AL, Tiedje J, van Elsas JD, Rosado AS, Peixoto RS (2011) Mangrove bacterial diversity and the impact of oil contamination revealed by pyrosequencing: bacterial proxies for oil pollution. PloS One 6(3):e16943

Dowd SE, Callaway TR, Wolcott RD, Sun Y, McKeehan T, Hagevoort RG, Edrington TS (2008a) Evaluation of the bacterial diversity in the feces of cattle using $16 \mathrm{~S}$ rDNA bacterial tagencoded FLX amplicon pyrosequencing (bTEFAP). BMC Microbiol 8(1):125

Dowd SE, Sun Y, Secor PR, Rhoads DD, Wolcott BM, James GA, Wolcott RD (2008b) Survey of bacterial diversity in chronic wounds using pyrosequencing, DGGE, and full ribosome shotgun sequencing. BMC Microbiol 8:43

Drever JI (1973) The preparation of oriented glay mineral specimens for X-ray diffraction analysis by a filter-membrane peel technique. Am Miner 58:553-554

Edgar RC (2010) Search and clustering orders of magnitude faster than BLAST. Bioinformatics 26(19):2460-2461

Elshahed MS, Senko JM, Najar FZ, Kenton SM, Roe BA, Dewers TA, Spear JR, Krumholz LR (2003) Bacterial diversity and sulfur cycling in a mesophilic sulfide-rich spring. Appl Environ Microbiol 69(9):5609-5621

Engle VD (2011) Estimating the provision of ecosystem services by Gulf of Mexico coastal wetlands. Wetlands 31(1):179-193

Evans FF, Rosado AS, Sebastian GV, Casella R, Machado PL, Holmstrom C, Kjelleberg S, Elsas JD, Seldin L (2004) Impact of oil contamination and biostimulation on the diversity of indigenous bacterial communities in soil microcosms. FEMS Microbiol Ecol 49(2):295-305

Glória Pereira M, Mudge SM, Latchford J (2002) Consequences of linseed oil spills in salt marsh sediments. Mar Pollut Bull 44(6):520-533

Grabowski A, Nercessian O, Fayolle F, Blanchet D, Jeanthon C (2005) Microbial diversity in production waters of a lowtemperature biodegraded oil reservoir. FEMS Microbiol Ecol 54(3):427-443

Gupta RS (2006) Molecular signatures (unique proteins and conserved indels) that are specific for the epsilon proteobacteria (Campylobacterales). BMC Genom 7:167

Hasegawa R, Toyama K, Miyanaga K, Tanji Y (2014) Identification of crude-oil components and microorganisms that cause souring 
under anaerobic conditions. Appl Microbiol Biotechnol 98(4): 1853-1861

Hazen TC, Dubinsky EA, DeSantis TZ, Andersen GL, Piceno YM, Singh N, Jansson JK, Probst A, Borglin SE, Fortney JL, Stringfellow WT, Bill M, Conrad ME, Tom LM, Chavarria KL, Alusi TR, Lamendella R, Joyner DC, Spier C, Baelum J, Auer M, Zemla ML, Chakraborty R, Sonnenthal EL, D'Haeseleer P, Holman HY, Osman S, Lu Z, Van Nostrand JD, Deng Y, Zhou J, Mason OU (2010) Deep-sea oil plume enriches indigenous oildegrading bacteria. Science 330(6001):204-208

Head IM, Jones DM, Röling WF (2006) Marine microorganisms make a meal of oil. Nat Rev Microbiol 4(3):173-182

Hedlund BP, Geiselbrecht AD, Bair TJ, Staley JT (1999) Polycyclic aromatic hydrocarbon degradation by a new marine bacterium, Neptunomonas naphthovorans gen. nov., sp. nov. Appl Environ Microbiol 65(1):251-259

Hemalatha S, Veeramanikandan P (2011) Characterization of aromatic hydrocarbon rading bacteria from petroleum contaminated sites. J Environ Prot 2:243

Hernandez-Raquet G, Budzinski H, Caumette P, Dabert P, Le Menach K, Muyzer G, Duran R (2006) Molecular diversity studies of bacterial communities of oil polluted microbial mats from the Etang de Berre (France). FEMS Microbiol Ecol 58(3):550-562

Herrmann S, Kleinsteuber S, Chatzinotas A, Kuppardt S, Lueders T, Richnow HH, Vogt C (2010) Functional characterization of an anaerobic benzene-degrading enrichment culture by DNA stable isotope probing. Environ Microbiol 12(2):401-411

Howarth RW (1984) The ecological significance of sulfur in the energy dynamics of salt marsh and coastal marine sediments. Biogeochemistry 1(1):5-27

Hubert CR, Oldenburg TB, Fustic M, Gray ND, Larter SR, Penn K, Rowan AK, Seshadri R, Sherry A, Swainsbury R, Voordouw G, Voordouw JK, Head IM (2012) Massive dominance of Epsilonproteobacteria in formation waters from a Canadian oil sands reservoir containing severely biodegraded oil. Environ Microbiol 14(2):387-404

Hughes JB, Hellmann JJ (2005) The application of rarefaction techniques to molecular inventories of microbial diversity. Methods Enzymol 397:292-308

Kim JN, Kim BS, Kim SJ, Cerniglia CE (2012) Effects of crude oil, dispersant, and oil dispersant mixtures on human fecal microbiota in an in vitro culture system. MBio 3(5):e00376-12

Kimes NE, Callaghan AV, Aktas DF, Smith WL, Sunner J, Golding B, Drozdowska M, Hazen TC, Suflita JM, Morris PJ (2013) Metagenomic analysis and metabolite profiling of deep-sea sediments from the Gulf of Mexico following the Deepwater Horizon oil spill. Front Microbiol 4:50

Klepac-Ceraj V, Bahr M, Crump BC, Teske AP, Hobbie JE, Polz MF (2004) High overall diversity and dominance of microdiverse relationships in salt marsh sulphate-reducing bacteria. Environ Microbiol 6(7):686-698

Kok M, Oldenhuis R, Van Der Linden M, Raatjes P, Kingma J, van Lelyveld PH, Witholt B (1989) The Pseudomonas oleovorans alkane hydroxylase gene. Sequence and expression. J Biol Chem 264(10):5435-5441

Kostka JE, Prakash O, Overholt WA, Green SJ, Freyer G, Canion A, Delgardio J, Norton N, Hazen TC, Huettel M (2011) Hydrocarbon-degrading bacteria and the bacterial community response in Gulf of Mexico beach sands impacted by the Deepwater Horizon oil spill. Appl Environ Microbiol 77(22):7962-7974

Kryachko Y, Dong X, Sensen CW, Voordouw G (2012) Compositions of microbial communities associated with oil and water in a mesothermic oil field. Antonie Van Leeuwenhoek 101(3):493-506

Kurkela S, Lehvaslaiho H, Palva ET, Teeri TH (1988) Cloning, nucleotide sequence and characterization of genes encoding naphthalene dioxygenase of Pseudomonas putida strain NCIB9816. Gene 73(2):355-362

Kvenvolden KA, Cooper CK (2003) Natural seepage of crude oil into the marine environment. Geo-Mar Lett 23(3-4):140-146

Lane DJ, Pace B, Olsen GJ, Stahl DA, Sogin ML, Pace NR (1985) Rapid determination of $16 \mathrm{~S}$ ribosomal RNA sequences for phylogenetic analyses. Proc Natl Acad Sci USA 82(20): 6955-6959

Laramee L, Lawrence JR, Greer CW (2000) Molecular analysis and development of $16 \mathrm{~S}$ rRNA oligonucleotide probes to characterize a diclofop-methyl-degrading biofilm consortium. Can J Microbiol 46(2):133-142

Li H, Zhang Y, Li DS, Xu H, Chen GX, Zhang CG (2009) Comparisons of different hypervariable regions of rrs genes for fingerprinting of microbial communities in paddy soils. Soil Biol Biochem 41(5):954-968

Liang JB, Chen YQ, Lan CY, Tam NFY, Zan QJ, Huang LN (2007) Recovery of novel bacterial diversity from mangrove sediment. Mar Biol 150(5):739-747

Liu Z, Liu J (2013) Evaluating bacterial community structures in oil collected from the sea surface and sediment in the northern Gulf of Mexico after the Deepwater Horizon oil spill. Microbiologyopen 2(3):492-504

Liu Z, DeSantis TZ, Andersen GL, Knight R (2008) Accurate taxonomy assignments from $16 \mathrm{~S}$ rRNA sequences produced by highly parallel pyrosequencers. Nucleic Acids Res 36(18):e120

Lozupone C, Hamady M, Knight R (2006) UniFrac - an online tool for comparing microbial community diversity in a phylogenetic context. BMC Bioinformatics 7(1):371

Lozupone CA, Hamady M, Kelley ST, Knight R (2007) Quantitative and qualitative beta diversity measures lead to different insights into factors that structure microbial communities. Appl Environ Microbiol 73(5):1576-1585

Mason OU, Hazen TC, Borglin S, Chain PS, Dubinsky EA, Fortney JL, Han J, Holman HY, Hultman J, Lamendella R, Mackelprang R, Malfatti S, Tom LM, Tringe SG, Woyke T, Zhou J, Rubin EM, Jansson JK (2012) Metagenome, metatranscriptome and single-cell sequencing reveal microbial response to Deepwater Horizon oil spill. ISME J 6(9):1715-1727

Mesarch MB, Nakatsu CH, Nies L (2000) Development of catechol 2,3-dioxygenase-specific primers for monitoring bioremediation by competitive quantitative PCR. Appl Environ Microbiol 66(2):678-683

Mitsch WJ, Gosselink JG (2000) The value of wetlands: importance of scale and landscape setting. Ecol Econ 35(1):25-33

Muyzer G, de Waal EC, Uitterlinden AG (1993) Profiling of complex microbial populations by denaturing gradient gel electrophoresis analysis of polymerase chain reaction-amplified genes coding for 16S rRNA. Appl Environ Microbiol 59(3):695-700

Nakai C, Kagamiyama H, Nozaki M, Nakazawa T, Inouye S, Ebina Y, Nakazawa A (1983) Complete nucleotide sequence of the metapyrocatechase gene on the TOI plasmid of Pseudomonas putida mt-2. J Biol Chem 258(5):2923-2928

National Health Environmental Effects Research Laboratory (US) Gulf Ecology Division (1999) The ecological condition of estuaries in the Gulf of Mexico, vol 98. US Environmental Protection Agency, Office of Research and Development, The Office, Gulf Breeze, Fla. vol 4

Panicker G, Mojib N, Aislabie J, Bej AK (2010) Detection, expression and quantitation of the biodegradative genes in Antarctic microorganisms using PCR. Antonie Van Leeuwenhoek 97(3):275-287

Pavlova A, Papazova D (2003) Oil-spill identification by gas chromatography-mass spectrometry. J Chromatogr Sci 41(5):271-273 
Phelps CD, Kerkhof LJ, Young LY (1998) Molecular characterization of a sulfate-reducing consortium which mineralizes benzene. FEMS Microbiol Ecol 27(3):269-279

Phillips CJ, Paul EA, Prosser JI (2000) Quantitative analysis of ammonia oxidising bacteria using competitive PCR. FEMS Microbiol Ecol 32(2):167-175

Pomeroy LR (1974) The ocean's food web, a changing paradigm. Bioscience 24(9):499-504

Pope PB, Mackenzie AK, Gregor I, Smith W, Sundset MA, McHardy AC, Morrison M, Eijsink VG (2012) Metagenomics of the svalbard reindeer rumen microbiome reveals abundance of polysaccharide utilization loci. PloS One 7(6):e38571

Prabagaran SR, Manorama R, Delille D, Shivaji S (2007) Predominance of Roseobacter, Sulfitobacter, Glaciecola and Psychrobacter in seawater collected off Ushuaia, Argentina, SubAntarctica. FEMS Microbiol Ecol 59(2):342-355

Price MN, Dehal PS, Arkin AP (2009) FastTree: computing large minimum evolution trees with profiles instead of a distance matrix. Mol Biol Evol 26(7):1641-1650

Ratajczak A, Geissdorfer W, Hillen W (1998) Alkane hydroxylase from Acinetobacter sp. strain ADP1 is encoded by alkM and belongs to a new family of bacterial integral-membrane hydrocarbon hydroxylases. Appl Environ Microbiol 64(4):1175-1179

Redmond MC, Valentine DL (2012) Natural gas and temperature structured a microbial community response to the Deepwater Horizon oil spill. Proc Natl Acad Sci USA 109(50):20292-20297

Ritchie KB, Keller BD (2008) A scientific forum on the Gulf of Mexico: The Islands in the Stream Concept. Marine Sanctuaries Conservation Series NMSP-08-04. US Department of Commerce, National Oceanic and Atmospheric Administration, National Marine Sanctuary Program, Silver Spring, MD, pp 105

Roling WF, Milner MG, Jones DM, Lee K, Daniel F, Swannell RJ, Head IM (2002) Robust hydrocarbon degradation and dynamics of bacterial communities during nutrient-enhanced oil spill bioremediation. Appl Environ Microbiol 68(11):5537-5548

Roling WF, Milner MG, Jones DM, Fratepietro F, Swannell RP, Daniel F, Head IM (2004) Bacterial community dynamics and hydrocarbon degradation during a field-scale evaluation of bioremediation on a mudflat beach contaminated with buried oil. Appl Environ Microbiol 70(5):2603-2613

Sette LD, Simioni KC, Vasconcellos SP, Dussan LJ, Neto EV, Oliveira VM (2007) Analysis of the composition of bacterial communities in oil reservoirs from a southern offshore Brazilian basin. Antonie Van Leeuwenhoek 91(3):253-266

Shannon CE, Weaver W, Blahut RE, Hajek B (1964) The mathematical theory of communication. University of Illinois press, Urbana
Shannon P, Markiel A, Ozier O, Baliga NS, Wang JT, Ramage D, Amin N, Schwikowski B, Ideker T (2003) Cytoscape: a software environment for integrated models of biomolecular interaction networks. Genome Res 13(11):2498-2504

Silliman BR, van de Koppel J, McCoy MW, Diller J, Kasozi GN, Earl K, Adams PN, Zimmerman AR (2012) Degradation and resilience in Louisiana salt marshes after the BP-Deepwater Horizon oil spill. Proc Natl Acad Sci USA 109(28):11234-11239

Simpson EH (1949) Measurement of diversity. Nature 163(4148):688

Sogin ML, Morrison HG, Huber JA, Mark Welch D, Huse SM, Neal PR, Arrieta JM, Herndl GJ (2006) Microbial diversity in the deep sea and the underexplored "rare biosphere". Proc Natl Acad Sci USA 103(32):12115-12120

Sundarakrishnan B, Pushpanathan M, Jayashree S, Rajendhran J, Sakthivel N, Jayachandran S, Gunasekaran P (2012) Assessment of microbial richness in pelagic sediment of Andaman sea by bacterial tag encoded FLX titanium amplicon pyrosequencing (bTEFAP). Indian J Microbiol 52(4):544-550

Teal JM (1986) The ecology of regularly flooded salt marshes of New England: a community profile. Biological Report, vol 85 . Woods Hole Oceanographic Institution, USA

van Beilen JB, Wubbolts MG, Witholt B (1994) Genetics of alkane oxidation by Pseudomonas oleovorans. Biodegradation 5(3-4):161-174

van Beilen JB, Smits TH, Whyte LG, Schorcht S, Rothlisberger M, Plaggemeier T, Engesser KH, Witholt B (2002) Alkane hydroxylase homologues in gram-positive strains. Environ Microbiol 4(11):676-682

Wang Q, Garrity GM, Tiedje JM, Cole JR (2007) Naive Bayesian classifier for rapid assignment of rRNA sequences into the new bacterial taxonomy. Appl Environ Microbiol 73(16):5261-5267

Whyte LG, Hawari J, Zhou E, Bourbonniere L, Inniss WE, Greer CW (1998) Biodegradation of variable-chain-length alkanes at low temperatures by a psychrotrophic Rhodococcus sp. Appl Environ Microbiol 64(7):2578-2584

Wirsen CO, Sievert SM, Cavanaugh CM, Molyneaux SJ, Ahmad A, Taylor LT, DeLong EF, Taylor CD (2002) Characterization of an autotrophic sulfide-oxidizing marine Arcobacter sp. that produces filamentous sulfur. Appl Environ Microbiol 68(1):316-325

Yakimov MM, Timmis KN, Golyshin PN (2007) Obligate oildegrading marine bacteria. Curr Opin Biotechnol 18(3):257-266

Yanez-Arancibia A, Day JW (2004) The Gulf of Mexico: towards an integration of coastal management with large marine ecosystem management. Ocean Coast Manag 47(11-12):537-563 